\title{
TH University of Glasgow
}

Parker, L. D. and Boyns, T. (2019) Language in pursuit of professional branding: the case of scientific costing. British Accounting Review, 51(2), pp. 193-210. (doi:10.1016/j.bar.2018.09.001)

There may be differences between this version and the published version. You are advised to consult the publisher's version if you wish to cite from it.

http://eprints.gla.ac.uk/168906/

Deposited on: 14 September 2018

Enlighten - Research publications by members of the University of Glasgow http://eprints.gla.ac.uk 


\title{
LANGUAGE IN PURSUIT OF PROFESSIONAL BRANDING: THE CASE OF SCIENTIFIC COSTING
}

\author{
Distinguished Professor Lee Parker \\ RMIT University, Melbourne Australia \\ The University of Glasgow, Scotland, UK \\ Professor Trevor Boyns \\ Cardiff Business School, \\ Colum Drive, \\ Cardiff, CF10 3EU. \\ Email Address: boyns@ cardiff.ac.uk
}

\begin{abstract}
Acknowledgements
This paper's development has benefited from the critical comments and advice received from colleagues at presentations made at the Universities of Glasgow, Edinburgh, Dundee, La Trobe University (Melbourne), and Auckland University (New Zealand) and as an invited plenary paper to the University of New South Wales Management Accounting Research Colloquium. We are also indebted to critical advice provided by Professors Lisa Evans (Stirling University), Kerry Jacobs (UNSW Canberra), John Burns (University of Exeter), Jim Haslam (Heriot Watt University), Wai Fong Chua (University of New South Wales), Jan Mouritsen (Copenhagen Business School), Ken Shackleton, John Holland, John McKernan, Clive Emmanuel, and John Eldridge (Glasgow University), Ian Thompson (University of Strathclyde), Ingrid Jeacle (University of Edinburgh), Larry O'Connor (La Trobe University) and Steve Walker (Edinburgh University).
\end{abstract}




\section{LANGUAGE IN PURSUIT OF PROFESSIONAL BRANDING: THE CASE OF SCIENTIFIC COSTING}

\section{Introduction}

In her seminal article on the development of cost accounting in the UK between 1914 and 1925, Anne Loft (1986) considered the diverse ways in which the roles of cost accounting and cost accountants were inter-woven with the social, economic and political life of the period, identifying British cost accounting's role in the post-war reconstruction of the economy and the emergence of the ICWA as an important post-war development (Loft, 1986: 152-155). ${ }^{1}$ In discussing its emergence, Loft considered the poor reputation of ICWA's membership among chartered and incorporated accountants and highlighted the discourse around cost accounting which claimed for it the status of 'science' in which post-WWI cost accountants tried to present themselves as the professional collectors and processors of these scientific 'facts' (Loft, 1986). Her analysis of the ICWA's emergence linked the rise of scientific costing with the development of scientific management.

Building on Loft's foundational research, this study examines the factors which contributed to the failure of the ICWA's 1923 attempt to obtain a Royal Charter. In particular, we consider the significance of the linking of cost calculation ${ }^{2}$ and science from the final decades of the nineteenth century, the development of scientific linkages with British cost calculation between the 1890s and c.1930, and the connection between the phrase 'scientific costing', key individuals within the ICWA hierarchy and the failed Royal Charter bid. This study focuses on the changing use of language surrounding cost calculation in Britain in the late nineteenth and early twentieth centuries. It addresses the specific term 'scientific costing' and its role in cost and works accountants' attempt to enhance their technical and professional branding and status.

The focal point of this study is to penetrate the reasons behind the emergence, use and rapid demise of the use of the term 'scientific costing' in the context of the professionalisation of cost accounting in Britain in the early 1920s. It therefore contributes to the understanding of the development of the modern British accounting profession and draws contemporary lessons from an historical attempt at branding strategies for enhancing professional status and recognition. The study's objective is therefore to investigate how and why scientific costing emerged and then disappeared in the context of professional cost accounting discourse of the late $19^{\text {th }}$ and early $20^{\text {th }}$ centuries. Accordingly the paper examines the changing discourse and linkage between costing and notions of science of that period. It also investigates the relationship between scientific costing and institutional contests over cost accounting and its professional status.

The research conducted for this study is based on an analysis of the accounting literature of the time; a review of the evidence presented in the works of Anne Loft; and papers related to the ICWA's Royal Charter application 1923-4 which were not available to Loft. Furthermore this study addresses a longer period than previously considered. Hence the study builds on Loft's analysis, providing some reinterpretation of events in the early phase of development of the ICWA between 1919 and 1925, with particular lessons being 
drawn regarding professional accounting association branding strategies. While the study initially presents itself as offering a specific and historical focus, it offers a long-term contextual analysis and critique of the post 1880s attempt to link accounting and science. This is done through the micro study of 'scientific costing' and its links with the early development of the ICWA (the forerunner of the modern CIMA). By so doing it offers a critical reflection on the strategy of linking the fortunes of any (particularly new) organisation to specific (time-dependent) terminology.

The remainder of the paper is structured as follows. In the next section we preface our study with a brief consideration of language and its meaning, before in section 3 going on to explain our research design and methodology, which is then applied in section 4 to examine the changing terminology associated with cost calculation in the accounting literature of the period c.1890-c.1930. Having noted the short-lived occurrence of the phrase 'scientific costing', we then investigate its rise and demise. Rather than moving directly to this issue, in section 5 we consider the changing relationship over the study period between science, art and accounting and then, in section 6, that between science and cost calculation. Section 7 covers the attempted institutional branding and reasons for the failed Royal Charter bid and demise of 'scientific costing', with Section 8 drawing lessons for professional association branding strategies. We then draw together our conclusions in the final section.

\section{Hermeneutical insights: language and meaning}

The relationship between the language employed in accounting and the language of the culture and period in which it is set is one of interest to accountants (R.H. Parker, 1994). Miller and Napier (1993) have argued that language is performative, in that it can be employed to define ways of calculating and vest them with approval and significance, depicting them as solutions to problems and normalised ways of proceeding in a particular domain. They link this performative role for example to the collective adoption of particular concepts, definitions and modes of calculation by professional associations which then point to them as 'arbiters of economic reality' (Miller and Napier, 1993: 633). Thus calculative practices are discursively created for example by the accounting profession so as to construct a 'special idiom' that comes to be used with their own particular interpretations by professional insiders. Such discourse protects the accounting profession's domain, insulating it from outside interference by the state, competitors, clients and others (Robson, Willmott, Cooper and Puxty, 1994).

The Sapir-Whorf hypothesis contends that our use of language reflects our surrounding culture and influences both perception and thinking (Evans, 2004). Thus language employed, associated perceptions and resultant decisions made can all be intertwined as well as being culturally and organisationally relativistic (Belkaoui, 1990). In this sense accounting concepts and terminology may be culturally perceived. What a signifier (e.g. a word or term) signifies (its underlying conceptualisation and meaning) is determined by the framework of other signifiers employed and the cultural setting in which it is communicated (De Saussure, 1966). Thinking is influenced by language as it offers a 
cognitive means of developing mental labels. Hence the choice and articulation of accounting terms may both attempt to reflect their environmental setting and what they signify relative to that setting (Evans, 2004).

Terms, calculative devices and definitions are accumulated at the boundaries of the accounting discipline as accounting expands its scope of practice and hence its boundaries (Miller, 1998). Accounting vocabulary thereby constitutes meaning, practice and a professional domain and reputation. Indeed such agreed vocabulary can be used to identify and demarcate the membership of what McMillan (1999) terms 'a community of the competent', conferring upon members unique status, recognition and economic power. Nevertheless, as Miller (1998) rightly points out, the accretion of concepts, terms and calculations by such a profession as accounting, gradually welds together fragmented, disparate elements that represent improvisations, adaptations, false starts, and borrowings from other disciplines, thereby producing a bricolage. As we shall see below, one such false start was that provided by 'scientific costing', a term that was adopted by leading figures of the ICWA in the early 1920s in an attempt to help legitimise its identity, status and control of an occupational domain (Gyarmati, 1975).

This study of the emergence and demise of scientific costing, as both linguistic heritage and as text (Boland, 1993; Prasad, 2002), aims to better understand the historical mentality and processes of the community of accounting professionals and their leaders, through an analysis of their actions, submissions, institutional language and discourse (Dilthey, 1976; Schleiermacher, 1985; Prasad, 2002). Our interpretation includes a critique of underlying organisational/political agendas underpinning past actions and strategies. This considers context as a means of further enhancing our understanding of the historical text (Prasad, 2002) and penetrating the meanings behind historical social actions (Llewellyn, 1993). As we see in this ICWA case, such actions can be understood as outcomes of leaders' social strategies and as social products of the organisation and its interaction with its institutional environment. This facilitates interpretation of social actions involved in the emergence and demise of scientific costing. Such a pattern can be exposed by critical hermeneutical reflection as professional attempts at the exercise of power and legitimation, with language as a key weapon (Llewellyn, 1993; Kosmala, 2005). For this study, language was not only a tool, but was ontologically significant; playing a part in constituting the social world of the actors (Prasad, 2002). As Habermas (1990) argued, language and its structures can be a powerful ideological medium for reflecting a conventionally understood tradition and as a medium for the exercise of social power and domination over institutional and organisational culture and structures (Prasad, 2002; Kosmala, 2005).

\section{Research design and methodology}

Our historical analysis is presented as an interpretive study that aims to provide both explanation and critique of the subject under study. It portrays significant stakeholders and events in the history of the development of cost calculation, including ICWA's initial, unsuccessful bid for professional status and jurisdiction in the early 1920s. In doing so, 
we reflect upon the events and structures pertaining at the time, as well as their social, economic and institutional environment (Tholfsen, 1967; Tosh and Lang, 2002). Events, decisions and conditioning influences have been critically appraised for changing patterns of language and discourse over time (Bedeian, 1998; von Humboldt, 2008). Of course, argument and judgement are required for this historical construction and assessment of environmental interactions and implications (Barzun and Graff, 1985; Stanford, 1998). Through this process the paper aims to deliver an authentic and credible historical account of the events over the period c.1890 to c.1930 which surrounded the early professionalization process (Atkinson, 1978) of British cost accountancy. Such a study assists in further opening up windows into the development of cost calculation and accounting professionalization, catching glimpses of past precedents and choices that have led to our contemporary professional world (Parker, 1999). In reflecting on our historiographic orientation, we recognise associated methodological limitations. One history cannot represent all possible evidence about a particular set of historical events, players, and circumstances. Inevitably the development of a narrative and associated explanations results from researcher judgement in selecting elements and configuring them into patterns, interpretations and explanations (Elton, 1967). Nor can we lay claim to isolating the causes of key events, but are limited to offering arguments for plausible and probable influences (Leff, 1971; Previts, Parker and Coffman, 1990).

This paper is in part inspired by, but moves beyond Boyns and Edwards' (2013) general history of British management accounting. Their text alludes to some of the issues addressed in this paper, but does so in a much more generalised way and in a broader (longer-term) context than the specific analysis of key issues presented in this paper. In particular, the paper provides a more detailed analysis of the issue of 'scientific costing' through its examination of the journal literature and identifies and analyses the phrase 'scientific costing', not used in the texts focussed upon and examined by Boyns and Edwards (2013). Furthermore, this study greatly expands the attention paid to the ICWA's failed Royal Charter bid, and offers hitherto unavailable explanations as well as drawing inferences for professional association branding strategies not previously considered in the accounting literature.

Our study utilises a number of different sources. The starting point is the previous work of Loft, both her 1986 article in Accounting, Organizations and Society and her 1990 book, Coming into the Light, which details the early history of the ICWA based upon a thorough examination of the ICWA's archives. Given Loft's forensic examination of the surviving archives we have not attempted to replicate this work, though we have made use of surviving ICWA membership lists from the 1920s. Building on Loft's work, we systematically surveyed the key contemporary accounting related literature covering the period between c. 1890 and c.1930 for references to cost calculation, focusing specifically on the terminology used. The literature examined included the two key professional accounting journals, The Accountant and, from 1921, the ICWA's own organ, The Cost Accountant, together with publications such as the Times and the Economist. The accounting texts examined included those readily identified in the widely-accepted standard histories of cost accountancy, viz. Edwards (1937), Solomons (1952), Garner 
(1954), etc., as key works of the study period and which were readily available for consultation at the British Library.

Given their age, the vast majority of the sources (i.e. contemporary texts, professional journals, etc.) were only available in hard copy format and therefore had to be searched visually, a process not without its inherent deficiencies. Items available electronically (e.g. The Economist (The Economist Historical Archive, 1843-2006), the Times (The Times Digital Archive)) were searched using internal search engines, though cross-checking, both electronically and visually, revealed the reliability of these to be highly variable. Thus, while specific searches for a term such as 'scientific costing' might not throw up any positive results, a search for the term 'costing' could nevertheless reveal it being used alongside 'scientific' in the phrase 'scientific costing'! Variations on key search terms were also investigated, thus the terms 'science' and 'unscientific' were checked in addition to 'scientific' but, in general, positive hits were generally small in number, no hits being found for 'unscientific'. Where a phrase was identified by an electronic search, the whole article was then examined visually for content in the same manner as hard copy sources. In this way, important phrases were identified and searched for in other material through a feedback loop.

One other major source used in writing this paper was the folders held at The National Archives (UK) relating to the ICWA's failed 1923 Royal Charter application (TNA PC12/30). This source, which was only made available to researchers in 2000, was not open to Loft when she conducted her research in the late 1980s.

The story that is narrated in these pages is therefore one that has emerged inductively from a study of the various source materials. In large measure the analysis is qualitative but some attempt has been made to quantify the use of certain words or phrases in the indexes of particular sources in order to try to provide a more precise indication of the timing of changes in their use. As one might expect, changes in the use of terminology cannot be dated exactly, not least because there was never a clean break between the use of one term and that of another. However, our long-term study of terms used in the index of The Accountant (see below, especially Table 1) revealed that three key phrases - 'cost accounts', 'costing' and 'cost accounting' - predominated at specific periods of time, even though other terms can also be found in use. Moreover, our analysis reveals that 'scientific costing' was used for a very specific period, namely, between 1919 and 1924.

\section{The changing terminology of cost calculation, c.1890-c.1930}

The use of words and terminology in everyday life is never static, and the same is true of specific activities such as cost calculation. During the decades spanning the turn of the century, a period which has been famously referred to as the 'costing renaissance' (Solomons, 1952: 17), there was a rapid increase in the literature, not just books and textbooks but also journal articles, devoted to cost calculation. Surveying this literature reveals a lack of uniformity in the use of key words and terms, and no agreement as to what the field which subsequently came to be known as cost accounting (and even 
management accounting) should be called. Two of the earliest recognised British textbooks dedicated to the subject failed to use 'cost' or any derivative thereof in their titles: Factory Accounts (1887) written jointly by the electrical engineer Emile Garcke and the incorporated accountant John Manger Fells; and Textile Manufacturers' Bookkeeping (1889) written by the chartered accountant George Pepler Norton. ${ }^{3}$

A major source of articles on cost calculation which was published continuously between the 1880s and 1920s is The Accountant, "The organ of chartered accountants throughout the world" (from 1920, "The recognised weekly organ of chartered accountants and accountancy throughout the world"). This source is useful because it contains a detailed index and published not just original articles and texts of speeches presented before various groups of chartered accountants and students, but also reproduced those on topics of possible interest to accountants given to other groups, such as engineers, and/or published in other journals, including British and American accounting journals.

At this point, it should be noted that the authors might have expected to encounter the use of the term 'scientific costing' in professional engineering discourse, particularly in the light of existing research literature relating to cost and management accounting in the engineering world in the early $20^{\text {th }}$ century (Loft, 1986; Boyns, 2003; Boyns and Edwards, 2013; McLean, 1995; Fleming, McKinstry and Wallace, 2000; McKinstry, 1999; Mclean, 2013; McLean, McGovern and Davie, 2015). However our investigation of the engineering literature detected little interest in costing or scientific costing, so that as Boyns and Edwards (2013) also concluded, the engineers' role in the professionalization of accounting (including cost accounting) in the USA, does not appear to have been replicated in Britain. It appears that while engineers clearly played an important role in the American turf wars over cost accounting, in Britain, engineers as a professional group had little interest in the area, though some individuals clearly did play a significant role and some early American papers on cost calculation were reprinted in British versions of the American engineering literature. We also found that in Britain, engineers were not always as enamoured with scientific management as their American colleagues: in a series of critical editorials published in The Engineer from 1911 to 1914, disparaging statements were made about the "crude and harsh 'engineering' approach to higher productivity which ... was associated with some less enlightened sections of the American "efficiency movement"" (Child, 1969: 40). This may go some way to explain their lack of interest in costing, although the British tendency for groups to specialise in their own area, leaving different areas to others, in a non-competitive manner, may also have played a role. We do find that in the early 1920s, although the terms 'science' and 'scientific' began to appear within the indexes to The Engineer, this was usually in relation to the Department of Scientific and Industrial Research, or labour issues, not to issues related to accounting, costs or costing.

Returning to The Accountant 4 , an examination of its index reveals references to 'cost', both on its own and in various related forms, including 'cost accounts', 'costing', 'cost accounting', etc., though the number of occurrences was small before the turn of the 
century. ${ }^{5}$ An analysis of the indexes of The Accountant between 1901 and 1930, however, reveals interesting changes in the frequency of use of various terms (see Table 1).

[Insert Table 1 here - annual use of terms in The Accountant]

As can be seen from Table 1, the term 'costing' came to dominate in the UK after WWI, in contrast to the use of the term 'cost accounts' which had been the only term regularly used before 1906 and which dominated prior to $1919 .{ }^{6}$ However, in the year the ICWA was formed, references to 'costing' far outstripped those to 'cost accounts', a trend which was echoed in the early years of publication of The Cost Accountant. Between June 1921, when it first appeared, and May 1925, references to 'costing' in The Cost Accountant outstripped those to 'cost accounts' by a ratio of 5:1 (see Table 2). After a change in method of compiling the index between volumes IV (1924/5) and V (1925/6), use of the term 'cost accounts' in The Cost Accountant all but disappeared, while 'costing' shared the limelight with 'cost accounting'. Of course some could argue that 'costing' and 'cost accounts' might not be alternatives but refer to a common practice and process. However it is also possible that the term 'cost accounts' relates more to cost calculation from a double-entry perspective, while the term 'costing' may refer to cost calculation done outside the double-entry framework. The dominance of either such term in any particular geographic location may also reflect national predispositions, for example in the US where 'costing' has almost never been used, but 'cost accounting' has been the dominant term.

[Insert Table 2 here - use of terms in annual editions of The Cost Accountant]

According to Boyns and Edwards (2013: 216), an online search of two major bibliographic databases, COPAC ${ }^{7}$ and Worldcat $^{8}$, "supplemented by other textual material, reveals that 'costing' appeared in the titles of over $70 \%$ of the works [dealing with cost calculation] identified as published in Britain between 1880 and 1952". The language of cost calculation in Britain in the first half of the twentieth century was therefore clearly one of 'costing', in contrast to the USA, where it was either cost accounting or cost accountancy. Nevertheless, some of the texts which appeared before 1930 and which ultimately appeared in numerous editions often failed to use the term 'costing', namely: the incorporated accountant William Strachan's Cost Accounts: The Key to Economy in Manufacture, which appeared in six editions between 1902 and 1936; Cost Accounts by the chartered accountant and partner of George Touche, Leslie Whittem Hawkins, which ran to 10 editions between 1905 and 1943; and The Principles of Cost Accounting (1925) by the chartered accountant E. Miles Taylor, which reached its $6^{\text {th }}$ edition in 1938, and eventually a $12^{\text {th }}$ edition (authored by R.L. Lambert) in 1956 . In addition to such long-lived texts, there were many which appeared in just one, or at most two, editions, such works being more numerous after 1920.

Thus in terms of an emergent language in the costing or cost accounting field, we see a variety of terminology being employed on both sides of the Atlantic. This suggests that professional concepts and practices were still in their developmental phase, being formed and articulated by a variety of innovators, principally being individual practitioners and textbook and journal article authors publishing in professional accounting journals. 
Arguably, the field was ripe for attempts at domination of this realm of practice and its representation. Through this period, this emergent language took on the cloak of technicist terminology, while arguably concealing more significant potential for control of underlying institutional and professional ideologies and agendas (Habermas, 1984; Prasad, 2002).

The evidence of Tables 1 and 2, and also that of the phrases used in the titles of texts published up to 1930, reveals that while there was no universal agreement over the correct term to use to describe the field, there was a clear switch of emphasis in Britain after WWI from 'cost accounts' to 'costing'. Moreover, the search for an appropriate term to describe the field of cost calculation was but one element in the wider search for a standard terminology (Loft, 1986, 1990; Boyns and Edwards 2013: 215-224). The search for a standard terminology to represent and clearly identify the limits of the field revealed competition between elements within the practising accounting community seeking to legitimise and control access to this emergent subfield of accounting as it was then recognised (Llewellyn, 1993; Kosmala, 2005).

One phrase used by Loft (1986: 160-161; 1990), but otherwise not specifically focussed on by her, was 'scientific costing'. As Tables 1 and 2 reveal, between 1919 and 1924/5, the phrase was seemingly used on just a few occasions, although a fuller search of the relevant literature for this short period of time reveals a wider use, especially by key players within the ICWA. In order to better understand the reasons for this limited dalliance with the phrase, and to place it in its broader historical context, we examine the developing scientific context from c.1890 through to c.1930. This broader level of context offers the potential for a more comprehensive understanding of the emergence of scientific costing as a strategic language for attempting control over the costing sphere of practice (Habermas, 1990; Prasad, 2002).

\section{Science, art and accounting}

Whether accounting is a science, or simply an art or a technique, is an issue which, from time to time, has been the subject of discussion within the accounting literature. Interpreting the changing view of accounting as a science, however, is complicated by the fact that the conceptualisation of art and science is not something which has itself remained static through time, and the distinction between them has never been altogether clear, or the subject of agreement. In mid-nineteenth century Britain, Foster (1843: 8 quoted in Chambers, 1995: 850) felt that "Science is theory, art is practice", while Spencer (1861: 61 - quoted in Chambers, 1995: 850) argued that "every science is evolved out of its corresponding art". Moreover, for Spencer (1861: 50), "there must be practice and an accruing experience with its empirical generalization" before there could be science, while Foster (1843: 8) noted that "every art is dependent upon science for its truth and certainty".

By the early twentieth century there was a growing conviction that there was no clear distinction between science and art. Pearson (1911: 17 - quoted in Chambers, 1995: 849) wrote that "Our aesthetic judgment demands harmony between the representation and the 
represented, and in this sense science is often more artistic than modern art". Campbell (1919: 227 - quoted in Chambers, 1995: 849) went even further, suggesting that "Nothing could be more absurd than the attempt to distinguish between science and art". His rationale for this view was that:

Science is the noblest of the arts and men of science the most artistic of all artists. For science, like art, seeks to attain aesthetic satisfaction through the perceptions of the senses; and science, like art, is limited by the imposition of the material world on which it works.

If we were to equate science with systematic study then it could be argued that the linking of science with accounting can be traced back many centuries. However, in many respects, until the second half of the nineteenth century, the word science was more usually applied in relation to bookkeeping than to accounting per se. In Continental Europe, from the late eighteenth century onwards through to the twentieth century, a major subject of controversy was that relating to theories of accounts, a topic which barely registered in Britain (Mattessich, 2008: 26). Early writers concerned to develop a theory of accounts seemed to have done so from a pedagogic perspective, namely a science of bookkeeping. By the early nineteenth century the Italian/European tradition focussed on classifications which were largely designed to "explain the reality of the bookkeeping system or to demonstrate the aesthetic symmetry" (McMillan, 1998: 3), ignoring ontological issues, first seemingly taken up by the American, Foster (1837) (McMillan, 1998: 5-6).

This attempt to develop a more systematic approach to accounts represents the first of what Mattessich (2008) has described as the three stages of development in accounting in the nineteenth century. The second phase came about as the result of developments often referred to as the second industrial revolution between 1860 and 1890, with the final phase being represented by financial capitalism from 1890 onwards. This last phase saw the development of accounting education in commercial colleges and universities in many countries and especially in Continental Europe, with accounting becoming "the main pillar of the new twin disciplines of business economics and business administration" (Mattessich, 2008: 38). Thus, during the early decades of the twentieth century, building on the work of late nineteenth century writers, in Germany, Schmalenbach, Schmidt and others developed Betriebswirtschaftslehre. In the Netherlands, Limperg and others developed Bedrijfseconomie, whilst in Italy, the likes of Besta, Villa and Zappa developed Economia Aziendale. As a result, in Mattessich's opinion, "the foundations of most of the scientific accounting issues [for which solutions are still being sought or refined today] were created in the first half of this [twentieth] century and before" (Mattessich, 2008: 38).

While not a purely European development, it was within Continental Europe that the discussion of whether accounting was an art or a science really got underway and gained more ground in the second half of the nineteenth century (Hernández Esteve, 2003: 5). In the Anglo-Saxon world the view was largely that accounting was a technique or an art rather than a science, the approach being one, "oriented towards know-how than towards 
conceptual and epistemological explanations" (Hernández Esteve, 2003: 9). Heavily influenced by French authors, Spanish accounting writers reflected a system of thought based on Cartesian philosophy and it is during the last quarter of the nineteenth century that one can find explicit claims within Spanish texts to accounting being a science, and then in contradistinction to the art or technique of bookkeeping, a distinction which becomes enshrined in texts of the first quarter of the twentieth century (Hernández Esteve, 2003: 32-33). Despite the more pragmatic approach of the Anglo-Saxon world, where empirical inductivism played a key role (Bronowski and Mazlish, 1960: 229), the linking of methods of keeping accounts and science go back at least until the early eighteenth century. North (1714: 1 - quoted in Chambers, 1995: 24) expressed the view that the method of keeping accounts by means of double-entry bookkeeping "was worthy to be put among the sciences" because it was "so comprehensive and perfect". A century later, a similar view was echoed by Jackson (1809: 1 - quoted in Chambers, 1995: 24) who commented that "Bookkeeping ... is a science whose principles are so simple and solid". However, such references were relatively rare until the late nineteenth/early twentieth century.

Before the turn of the century, Charles Waldo Haskins and his fellow leaders of the New York Institute of Accounts were convinced that accounting was essentially scientific in nature. Thus, Haskins (1900: 1010 - quoted in Chambers, 1995: 10) firmly stated that accounting was a science and also suggested that "Scientific accountancy is the hub of the universe of commerce, trade and finance". Haskins' justification for such a view was that accountancy "thinks out, and thus finds out, with logical and mathematical accuracy, the condition of affairs of any business enterprise" (1900: 1010 - quoted in Chambers, 1995: 25). Around the same time, Sombart (1902, II: 119 - quoted in Chambers, 1995: 10) suggested that "Double entry bookkeeping is based on the principle of treating all phenomena simply as quantities, the principle of quantification which has brought to light all the wonders of scientific knowledge". The idea that accounting was a science was also supported amongst Anglo-Saxon authors by Lisle (1899: 1), Duncan (1909: 84) and Paton \& Stevenson (1917: 1), while Cole (1908: 4) referred to accounting as the "scientific analysis and record of business transactions" (quoted in Chambers, 1995: 29) and Smith (1912: 244) to the "science of accounting" (quoted in Chambers, 1995: 894). While there is clear evidence in the early decades of the twentieth century of some movement towards a wider acceptance of accounting as a science, the English author Carter (1923: 1 - quoted in Chambers, 1995: 25 - emphasis added) somewhat muddied the waters, by claiming that "bookkeeping is the science and art of correctly recording in books of account all those business transactions that result in the transfer of money and money's worth".

But what did it mean to claim that accounting was a science? In England, Pearson (1911: 12 - quoted in Chambers, 1995: 754) wrote that "The unity of all science consists alone in its method, not in its material". Contemporary opinion of the early twentieth century stressed the importance of the utilisation of principles, laws, theorems, etc., a view that was very much in line with more recent thinking such as that of Medawar (1986: 3 quoted in Chambers, 1995: 754): 
Science is organized knowledge ... Science is, or aspires to be, deductively ordered. It parades principles, laws and other general statements from which statements about ordinary particulars follow as theorems.

From this standpoint, method is the key to science, and it can be surmised that 'scientific accounting' implies the utilisation of systems and/or a systematic approach to accounting, based on various laws or principles. Contemporary comments in late nineteenth century Britain suggested that accounting was overtly attempting to become seen as more scientific. Thus, in 1894, in a series of short pieces on cost accounts in The Accountant, it was noted that over the past years "the financial books of manufacturing concerns were gradually raised to the very high state of practical and scientific excellence at which they now stand" (The Accountant, 1894: 655). A decade later, while noting that there were some who failed to recognise that there was a science of accountancy "which is distinct, though not necessarily apart, from the art of the accountant" (Fells, 1907: 198), J.M. Fells considered that accounting was nevertheless a progressive science (1907: 197).

The general societal context in which scientific costing was to initially emerge, therefore, was one of accountants observing, attempting to make sense of and position themselves relative to what they saw as the rise of science as a major societal phenomenon. Generally they did not articulate how they defined science and penetrating their concepts of science lies beyond the scope of this study. Nonetheless, they clearly saw a growing community esteem for the increasingly pervasive social ideology of a rational, scientific world which was penetrating industry and commerce, particularly through the agency of the scientific management school. This signified changing social and institutional orientations, processes and structures with which they wished accounting to be identified to ensure its ongoing legitimation and dominance in business and government. This was more than a technical agenda, but signified a desire to preserve what they wished accounting to be, an ideology at the centre of business affairs and societal functioning (Llewellyn, 1993; Prasad, 2002).

\section{Science and cost calculation}

\subsection{Continental Europe}

The development of streams of business economics within Germany, the Netherlands and Italy in the latter decades of the nineteenth and early decades of the twentieth century led to the development of a more scientific approach to cost accounting in some parts of Continental Europe. German academics such as Schmalenbach engaged in discourse and developments relating to what some of them saw as the science of cost accounting (Locke, 1979). Viewing accounting as an applied science, Schmalenbach focussed on attempting to develop it as a technology of business, relating costs to technological factors, building a model of management decision-making, and producing calculations and arguments that anticipated aspects of forecasting and standard costing (Locke, 1979). In the early decades of the 1900s he integrated the accounts of financial accounting and cost accounting to form the basis for a widely accepted industrial chart of accounts, which laid 
the foundations for uniform accounting that became pervasive across continental Europe. This ultimately became compulsorily required by the German state through the 1930s into the mid-1940s (von Colbe, 1996). The integrated uniform system of accounts also spread beyond German borders to attract uptake in such countries as France and Spain.

\subsection{Britain}

In Britain, where "British economists often appeared disdainful of accounting, and business administration in general" (Napier, 1996: 428) in the hundred years between 1850 and 1950, it was the search for Foster's 'truth and certainty' in the business world which underpinned the rhetoric that increasingly linked science and accounting in Britain in the late nineteenth century. Moreover, as we shall see below, discussion of the relationship between science and cost calculation began around this time, i.e. some 25-30 years prior to the outbreak of WWI and the events which formed the focus of the studies by Loft (1986; 1990). Hence her claim (Loft, 1986: 159-163) that it was during the period 1914-25, the years of 'coming into the light', that science and cost accounting came to be linked, fails to recognise that this period was but one phase within a longer development of accounting history. It is to this which we now turn our attention.

\subsubsection{Science and costing c.1888-c.1914}

The idea that costing was, in some senses, scientific and that it was (or needed to be) based on principles began to emerge from the early 1890s. In the late 1880s Warwick (1888: 655) referred to the need for "thoroughly systematic method" to be used in the counting house if the accuracy of cost accounts was to be ensured, but in the early 1890s references were made to introducing "a perfect system of Cost Accounts" (Plumpton, 1892: 271), and for formulating "Cost Accounts upon a scientific system" (The Accountant, 1894: 655). In the early 20th century, Bardsley (1902: 1053) advised students on what to do if they were called upon to "devise a scientific system of cost accounts", while Preen referred to "scientific product costings" (c.1909: 2) and a "scientific production costing system" (c.1909: 6), and Fells (1910: 69) alluded to the need being felt in both the western and eastern hemispheres "for scientific cost systems".

The literature on cost calculation reveals two themes linking cost calculation to science before WWI: the first, as noted by Loft (1986: 160), relates to cost systems by which to establish 'true' or 'actual' cost, and the second to the need for principles by which cost systems could be built. The latter included the question of whether cost accounts should be kept by double entry bookkeeping methods and/or integrated within the general accounting system. Although no definitive statements were made at the time, it seems clear that what differentiated a scientific from an unscientific system was the development and adoption of key principles, as evidenced by speakers and authors from the turn of the century (Goode, 1900: 601; Showell, 1901: 59; Craggs, 1915: 756). Some outlined systems from personal experience (Bardsley, 1902; Jenkinson, 1907), but in the judgement of John Mann Jr. (1903 [1978]: 131), the "systematic recording of costs is quite a modern innovation, and really scientific schemes are rare". 
The establishment of principles, however, seems not to have been a simple one. Thus, the leader writers of The Incorporated Accountants' Journal (1904: 175) noted at the beginning of the 20th century that "Cost Accounting ... [was] still in the stage of youthful development, with few settled principles". Indeed, by the eve of WWI, caution was being sounded by some authors on the subject. Burton (1912) pointed out that the general principles of cost accounts were far from agreed, while Jenkinson (1914) cautioned that the ideal costing system on paper may not work efficiently in practice.

Although it is far from clear to what extent and in what ways cost systems were considered scientific before WWI, or the extent to which principles had become well established, it is more than evident that a number of those involved in the formulation of cost calculation methods were sufficiently concerned about the matter to discuss the issue of science in relation to cost calculation in the decades leading up to the outbreak of WWI. Again, what appears to have been a profoundly technical orientation in this emergent costing discourse also, arguably, reflected a deeper desire for costing's ideological recognition by both business and professional accounting peers as a central pillar of the accounting discipline and as a separately identifiable and significant accounting philosophy and practice regime (Habermas, 1987; Prasad, 2002).

\subsubsection{The emergence of 'scientific costing'}

The linking of science and cost calculation continued into the war years: Elbourne (1915: 392) referred to the "scientific spirit in factory accounting", while Craggs (1915: 756) noted that the cost of an article can only be ascertained "by a scientific system of bookkeeping". During WWI it has been contended that, as a result of the impact of the Ministry of Munitions, accounting procedures which paid increasing attention to monitoring efficiency and tracking costs were more widely introduced (Marriner, 1980; Loft, 1986, 1990). By the end of WWI Massey (1919: 12) could remark that "of late years it [costing] has developed more on the lines of an exact science, certain broad principles having come to be recognised as standard and which form a basis on which to build up the individual system". Such a comment reflected a continuing pervasive tendency towards favouring some notional link between accounting principles and a general scientific approach.

Although many authors (Fells, 1919; Cathles, 1920; Bird, 1921) in the immediate postWWI years exhibited a concern with the establishment of costing principles, several individuals closely linked to the newly established ICWA began to use a new phrase, 'scientific costing'. The term 'costing', as noted above in our discussion of Tables 1 and 2 , began to dominate the accounting literature in Britain for the first time after the war, and continued to do so, alongside 'cost accounting', until at least 1930. But while 'costing' continued to play an important role after 1924, 'scientific costing' had only a short shelf-life. The first post-WWI use of 'scientific costing' 9 to have been identified is in an article in The Economist reviewing the presentation to the Industrial Reconstruction Council, on 28 January 1919, of a paper entitled 'The Workers' Interest in Costing' by Mark Webster Jenkinson. ${ }^{10}$ 'Scientific costing' was then picked up by the editorial team of The Accountant and used as a heading under which appeared a letter from the 
chartered accountant, E. Miles Taylor, announcing his intention to hold a conference on 'cost finding' (The Accountant, 1919a). Although Taylor himself did not use the phrase, his letter gave rise to a stream of correspondence in The Accountant through to July 1919 when it was summarily curtailed by the editor of the journal who added, following the printing of another letter from one of the key founders of the ICWA, R.J.H. (Dick) Ryall, on the topic, "We think this correspondence must now cease. - ED. Acct." (The Accountant, 1919d).

The early exchange of letters involved Taylor, Ryall and someone writing under the pseudonym 'SYSTEM', but none of the protagonists initially used the term 'scientific costing' in the text of their letters, although the letters continued to appear in The Accountant under this heading. Given this, it is perhaps not surprising that the term should eventually be picked up and repeated. The first of the communicants to use the phrase was James Sambidge, the then ICWA secretary, in his letter dated 13 May 1919. Paradoxically, this letter appeared not under the heading 'scientific costing' but that of 'The Institute of Cost Accountants' (The Accountant, 1919b). ${ }^{11}$ Ryall himself first used the term in a letter dated 2 June 1919, when he asked Taylor "to produce evidence to support his assertion that Chartered Accountants are the only persons capable of undertaking scientific costing" (The Accountant, 1919c). Having appeared in the indexes of volumes LX (January-June 1919) and LXI (July-December 1919) of The Accountant (see Table 1) in connection with this exchange of letters, the term 'scientific costing' failed to feature thereafter, though it did make a brief, but limited appearance in the indexes of The Cost Accountant (see Table 2). Such references, however, fail to reveal the full extent of the use of the phrase, whether in the titles of articles or other items, or within various pieces of text. Indeed, a closer examination of the pages of the early volumes of The Cost Accountant reveals that, having had the 'scientific costing' label attributed to their activities by the mouthpiece of the ICAEW, the term began to be taken up within the ICWA's own journal, even though the term is not one to be found amongst the official objectives of the ICWA as set out in its memorandum of association (ICWA, 1923: 22-23).

Loft (1986: 161) argued that by early 1922, the raison d'être of the ICWA was "being described as the advance of scientific costing" and cited J. Claud Todman's presentation (on behalf of ICWA's executive committee) of 'The necessity for scientific costing' at ICWA's first annual costing conference held in February 1922. ${ }^{12}$ However the term had been employed earlier by J.A. Wild (1921), FCWA (a fellow of the ICWA), in a paper published in parts in The Cost Accountant during the period August-November 1921. After Todman's 1922 presentation, the phrase was used several times in subsequent editions of the ICWA's journal appearing in an editorial in The Cost Accountant, (1922a: 155), in relation to an item in the 'Notes and Comments' column of the same edition (The Cost Accountant, 1922b) and in the following month's edition (The Cost Accountant, 1922d). Clearly these uses were closely linked to the appearance of the phrase in Todman's paper, and continued to be used through into 1923. For example it can be found in the opening sentence of an article by G.E. Whitehouse (1922), and in papers presented in late 1922 and early 1923 by several FCWAs, including P. Griffiths (1923) and S.L. Gill (1923a, 1923b). ${ }^{13}$ 
Thus emerged a highly specific terminology, 'scientific costing' around which some cost accounting discourse appeared to be coalescing. It appeared to symbolise a growing mood amongst some cost practitioners to identify what they saw as a promising accounting practice area with a societal esteem for the role and potential of science as a community and societal contributor and leader. At the institutional level therefore, it becomes evident that some key players in the governance and leadership of the ICWA had begun to take up scientific costing as a possibly potent symbolic term that could simultaneously present a technicist front while at the same time assisting their desire to dominate the emergent field of cost accounting practice (Habermas, 1990; Llewellyn, 1993; Kosmala, 2005).

\subsubsection{The demise of 'scientific costing'}

Between June 1923 and April 1925 only three instances of the use of the phrase 'scientific costing' in The Cost Accountant have been identified. It was used in the title of a short article by J.J. Evans (1923), within the text of the paper presented in November 1923 by an ICWA Council member, R. Stelling (1924), and in the title of a piece presented in March 1925 by A.W. Kirkaldy (1925), professor of economics and commerce at the University of Nottingham. Thereafter, use of the phrase is difficult if not impossible to find. Moreover, from the middle of 1923 it is possible to detect a subtle shift away from use of the term 'scientific costing' within the pages of The Cost Accountant. During the period in which it had been used, other terms, such as 'a proper system of costing', 'a scientific cost system', and such like had continued to be used alongside it, even within the same articles. However, while 'scientific costing' lost currency from 1923 onwards, these other terms did not. Thus F.W. Ewing (1923: 42) referred to the "science of costing", as did an editorial in The Cost Accountant (1923a: 181 ), in which was also used the phrase "scientific system of Cost Accountancy". In the 'Notes and Comments' section of the same edition of the journal, reference was made to the ICWA, somewhat disingenuously in the light of its failure to achieve a Royal Charter (see next section), as being "the only accredited Institute devoted to the science [of costing]" (The Cost Accountant, 1923b).

From this time onwards, although writers continued to link science and cost calculation, the phrase 'scientific costing' was shunned, even by writers who had previously used it. Gill, having referred to 'costing' as "this new science and art" (1925a: 366), in a subsequent paper referred to a 'scientific costing system' (Gill, 1925b: 62) and to the attainment of a specific cost 'scientifically' (Gill, 1925b: 67). In the later years of the 1920s, emerging key figures in the ICWA increasingly used alternatives to 'scientific costing'. Thus, Dunkerley proffered the view that 'Cost Accountancy is an analytical science' (1928: 282) while Griffiths (1929: 285) referred to 'scientific cost accounting'. ${ }^{14}$

How is it possible to understand this short-lived use of the phrase 'scientific costing'? In particular, having been developed outside of the ICWA, why was it rapidly embraced by some of its members and its journal, and then rapidly dropped from the middle of 1924 ? It would appear that for some reasons, its value as an identifier of desired linkages 
between costing and science had become suspect, at least in the eyes of those devoted to promoting the status and their control of this emergent area of accounting practice. As Loft $(1986 ; 1990)$ has shown, to better understand the events after WWI it is necessary to consider the environment faced by cost calculation in Britain at the time, and the opposition faced by the ICWA from existing professional organisations within accountancy. While Loft recognised the shift toward scientific costing, and briefly mentions the failed Royal Charter bid made by the ICWA in 1923/4, she failed to recognise the specific relationship between this failure and the rise and demise of the term 'scientific costing'. It is to this which we will now turn our attention.

\section{Attempting institutional rebranding}

Although not initially used by members of the newly formed ICWA, as we have noted, 'scientific costing' was seen as an important label, being enshrined in the title of the paper presented by Todman at ICWA's first National Cost Conference. This was at a time when, as Loft (1986: 156) has pointed out, the ICWA was in the "process of trying to establish themselves (sic.) as a legitimate professional accounting body". In essence, it was part of an ICWA attempted organisational branding strategy. What follows in this section is an analysis of the connections between the ICWA's professional recognition aspiration and changes in the ICWA's organisational leadership as well as their interpretations of the meaning of the phrase 'scientific costing' as part of their status reinforcing brand aspirations. This constituted part of the backdrop to the ICWA's application for a royal charter, its subsequent failure, and the impact of that failure on the currency of 'scientific costing' in the ICWA discourse and its focus.

\subsection{The organisational structure of ICWA}

The organisational structure of the ICWA in the early 1920s comprised a Council of 7-15 Fellows (ICWA, 1923: 26), with an Executive and Finance Committee of 3-7 council members overseeing day-to-day activities (ICWA, 1923: 44). The two leading lights in the formation of the ICWA were two work colleagues, Dick Ryall (cost accountant), and Claud Todman (electrical engineer). ${ }^{15}$ They were amongst the seven signatories to ICWA's memorandum and articles of association on 24 February 1919 (ICWA, 1923: 22-28) and, together with George Russell (works accountant) (Loft, 1990: 81), they played a key role in the organisation's early development, though it was Ryall, as Honorary Secretary, 'who dominated the affairs of the Institute in the early period' (Loft, 1990: 57), largely considering it to be 'his' Institute.

The early years of the ICWA were punctuated by financial difficulties, not to mention personal differences, such that the executive committee comprised two factions. In late 1922 three members of the executive committee, William Hudspith, Donald Moran and Reginald Townsend, after a "long drawn out disagreement with the other three" (Loft, 1990: 54), resigned, leaving just Ryall, Todman and Russell in charge. Although Loft's analysis does not suggest that the resignations had anything to do with 'scientific costing' or the submission of the Royal Charter petition, the timing is suggestive, being 
sandwiched between the delivery of Todman's paper at the first costing conference and the lodging of the charter petition. An important issue was the use and meaning of the term 'scientific costing', particularly as a vehicle for establishing an organisational brand that might support ICWA charter aspirations.

\subsection{The meaning of 'scientific costing'}

In the paper read on behalf of Council by Todman (1922), it was implied that 'scientific costing' represented an approach built upon general principles and the standardisation of costing terminology and methods (Todman, 1922). Stelling, a member of the ICWA's Council, in the discussion that followed Todman's presentation (The Cost Accountant, 1922e: 187) criticised the lack of a clear definition, personally favouring the term 'standardised costing' for what had been suggested, but since this term was used by many at the time as a synonym for uniform costing, it is not clear to see how this would have provided greater clarity. That there was a clear need for greater clarity in costing terminology in the early 1920s was one of the areas upon which there had been general agreement following discussions at the costing conference organised by Miles Taylor in June 1919. This conference had been attended by Ryall, who became a strong advocate of the development of a costing terminology by the ICWA during its early years. In the event, however, it took the ICWA until 1937 to publish its first, somewhat limited costing terminology (The Cost Accountant, 1937) and, since the term had by then long since lost any currency, 'scientific costing' was not included. ${ }^{16}$

\subsection{The Royal Charter petition}

The lack of agreement over the meaning of the term may explain why, in the Royal Charter application made in 1923, the term was not used explicitly, it merely being stressed that "the modern system under which cost accounts are kept is a scientific system" (TNA, PC12/30, folder 128078, Petition, para. (3)), and that modern production methods required "a very much more scientific and accurate system of 'costing' than was formerly necessary" (TNA, PC12/30, folder 128078, Petition, para. (6)). However the association with scientific method reinforced the image of ICWA as a professional body distinctively associated with the application of scientific methods. This arguably constituted a subtle attempt to establish an institutional brand associated with the rise of science as a major societal preoccupation and economic driver. This formed part of a context surrounding ICWA leaders' aspirations to obtain a Royal Charter as a means of establishing the profession of cost accountancy. However, the cost of obtaining a petition, put at some $£ 700$ in 1919 , was initially considered to be beyond the financial means of the fledgling body (Loft, 1990: 70). Despite this, in 1920 a Royal Charter Committee, comprising the whole of the executive committee, was set up and worked on the issue throughout 1921. However, it was Ryall who was the driving force behind the application, doing much of the drafting work himself (Loft, 1990: 70-71). By April 1922, the draft Petition, Charter and Bye-Laws were approved, but the need to raise sufficient funds delayed the submission to the Privy Council until 16 January 1923 (Loft, 1990: 71). 
The application was contested by a number of bodies, most prominently, but not exclusively ${ }^{17}$, the other chartered accountancy bodies, namely the Institute of Chartered Accountants in England \& Wales, The Institute of Chartered Accountants in Ireland and the Scottish bodies, all of whom lodged counter-petitions. Amongst the reasons for their objections were the short length of ICWA's existence and the small size of its membership, both absolutely and relatively (TNA, PC12/30, folder 128274). Founded in 1919, ICWA's membership had only reached 494 by 1923 (Banyard, 1985: 19). Despite the ICWA being given the chance to respond to the counter-petitions, following advice from the Government Actuary and the Board of Trade, the Privy Council rejected the ICWA's application, the decision being communicated by letter dated 31 May 1923. Although subsequent enquiries were made in the following twelve months to see if a reapplication might be successful, it is recorded that, in August 1924, the ICWA's solicitor was given "no encouragement" (comment on inside cover of TNA PC12/30 folder 128514) and the Institute then let the matter drop.

\subsection{The aftermath of the failed application}

Having failed to obtain a Royal Charter, and with no prospect of gaining one in the foreseeable future, two inter-related events then occurred. First, as already noted, the term 'scientific costing' largely disappeared from the cost calculation discourse of the ICWA and the professional accounting literature. Here was terminology that, as part of an organisational branding strategy, had attempted to associate costing with science being first employed and then discarded as part of a project of institutional professionalization. The unsuccessful charter bid represented not merely a significant setback for the ICWA but a major rebuff for the strategy of those who had led the organisation and been instrumental in the charter bid.

The second event resulting from the failed charter bid was a major re-organisation of the ICWA's structure. In her discussion of these events during the second half of 1923 and the first half of 1924, Loft (1990: Ch. 4, esp. 51-67) notes that this was a period of "turmoil", emphasising "personal disagreements and financial difficulties" (Loft, 1990: 54). Following the failure of the charter bid with which they had both been very closely associated, both Todman and Ryall resigned from the executive committee. Todman stood down as chairman of the executive committee almost immediately in June 1923 (Loft, 1990: 54) and Ryall informed the committee by letter on 27 July 1923 of his desire to retire from the position of Honorary Secretary (Loft, 1990: 57). Plans were then drawn up in the second half of 1923 by ICWA's council to make the organisation more democratic, the scheme subsequently being accepted at the fifth annual general meeting held on 29 February 1924 (Loft, 1990: 63). Under the scheme, the new Council would comprise 14 members elected by the regional associations and 10 co-opted members (Loft, 1990: 64). The first list of elected members was presented at an extraordinary general meeting held in May 1924 and, shortly afterwards, Ryall resigned from Council, effectively severing his formal ties with the body he had helped to form and had dominated previously. By the end of May 1924, the ICWA was effectively in new hands, "Russell being the only early activist still involved" (Loft, 1990: 54). ${ }^{18}$ 
The change of organisational structure and the rise of a new executive, shorn of the dominating influence of Ryall and Todman, made it easier for ICWA and its members to distance themselves from the past. ${ }^{19}$ Gradual acceptance that securing a Royal Charter was unlikely for many years, was accompanied by a severing of the links with the term 'scientific costing' and the apparent abandonment of its related branding strategy. Moreover, it also proved possible in the longer term to distance the activities of cost accountants from scientific management, a link which, it has been argued, had played an important role in the adoption of the term 'scientific costing' in the first place (Loft, 1986).

\subsection{Contributors to scientific costing brand failure}

Two particular contextual elements surrounding the ICWA during its branding and related Royal Charter attempt, at least in part, explain the failure that it experienced (Prasad, 2002). First the 1920s were a period of considerable scientific, technological, industrial, labour and political change and ferment in Britain, providing a more complex menu of offerings than that provided by a unitary science model. Further dilution of the fascination with 'scientific costing' came from the rise of the human relations school of management which rejected scientific management, choosing instead to approach organisational management through psychosocial factors focussing upon the management of interpersonal behaviour (Parker, 1986a). In addition, the decline of scientific costing was arguably accelerated by the bad press that scientific management was increasingly receiving in some quarters in Britain as the 1920s progressed. It must be remembered that as scientific management founder, Frederick Taylor reflected his North American environment and its values, contiguous with the rise of American industrial and political power (Parker and Ritson, 2011a). However in post-war UK, not only was there antiAmerican sentiment but, as unemployment became a more widespread feature of the economy, there also arose a backlash against scientific management. This became very marked in the late 1920s following attempts by some consultants, most notably the British Bedaux consultancy from 1926, to implement work study (time and motion) methods in some British firms. ${ }^{20}$ These attempts, many of which led to lengthy and violent strikes (Whitston, 1996), gave scientific management something of a bad name, particularly with the British trade union movement and an associated reluctance demonstrated by British employers to appear to associate with scientific management principles (Urwick, 1929; Parker and Ritson, 2011b). It became associated with falling employee morale, industrial unrest, and increased employee absenteeism and turnover (Sewell and Wilkinson, 1992), with Taylorism developing a reputation as the worker's enemy (Morgan, 1986). Indeed the human relations school of management was emerging around the time of the failed ICWA charter bid, and was actively campaigning against scientific management principles as root causes of British industrial ills outlined above.

Thus the move away from a community fixation upon scientific management, reinforced by personnel changes at the top of ICWA and the development of a new democratic organisation, arguably triggered ICWA misgivings about a strong identification with 'scientific costing', a term which had no generally accepted definition. Hence ICWA leaders began to respond to changes in what was being regarded as rational and appropriate strategy in their institutional environment. A symbol such as 'scientific 
costing', formerly taken up as having promising brand association utility, no longer fitted the revised internal goals of the organisation or changing external attitudes and expectations and was discarded. This reflects contemporary arguments and explanations for the uptake of and resistance to new management ideas outlined by Parker and Ritson (2016). Both historically and in the contemporary organisational and professional world, the uptake or resistance to new ideas has been argued to depend on (potential) users' interpretations and beliefs about what that idea really is and actually does for them (Benders and Van Veen, 2001). In the case of abandoning a concept such as scientific management or scientific costing, that decision can be triggered by an experienced difficulty convincing stakeholders of its merit, observing competing organisations failing to adopt it, or deciding that the idea is no longer path-breaking or able to deliver the promised benefits (Carson, Lanier, Carson and Birkenmeier, 1999; Benders and Van Veen, 2001; Ritson and Parker, 2016). This did not mean, however, that symbols were no longer considered important. The link between cost calculation and science continued to be made, as has already been noted, in papers presented by members of the new ICWA Council (Gill, 1925ab; 1927-8; Dunkerley, 1928; Griffiths, 1929) However no longer was any prominence given to the specific phrase 'scientific costing', nor did it appear to be employed as part of an organisational branding strategy.

A second factor that contributed to the demise of scientific costing as part of an ICWA branding strategy was the emergence of other developments within the domain of cost calculation vying for the limelight, including budgeting. While scientific management, scientific standards and costing as a science were the dominant currency of business, management and accounting writing and discourse during the 1890-1920 period, from this time onwards and through into the 1930s and 1940s, the focus of the scientific underpinning of cost calculation was increasingly subsumed under the broader focussed banner of corporate budgeting and budgetary control. Budgets, of course, had had a long pre-history, and articles on the topic of financial planning (Jenkins, 1922) and budgetary control (Perry-Keene, 1922-23) appeared in early editions of The Cost Accountant. Moreover, under the new organisational structure, ICWA's Council chose budgetary control as one of the two topics for discussion at the fourth costing conference held on 1 May 1925 (Perry-Keene, 1925; Quennell, 1925). Fleischman (2009) has argued that the rise of corporate budgeting in the 1920s in the USA, owed much to its considerable presence in local and state government budgeting practice. Associated budgeting theory and literature, he has argued, became increasingly prominent in the late 1920s and early 1930s. Arguably budgeting achieved greater prominence in Europe and the UK, following the attempt to reach a generally accepted definition of budgeting at the 1930 International Conference on Budgetary Control hosted by the International Management Institute in Geneva, Switzerland (National Industrial Conference Board, 1931; Dent, 1935; De Paula, 1948; Parker 1986ab, 2002). This shift towards a budgetary focus and discourse reflected general changes in cost accounting professional and literature discourse over a considerable period.

During the 1890-1920 period, scientific management, scientific standards and costing as a science were the dominant currency of business, management and accounting writing and discourse. From the mid to late 1920s and through into the 1930s and 1940s, this 
scientific underpinning was subsumed under the broader focussed banner of standard costs, corporate budgeting and budgetary control. After the 1930 International Conference on Budgetary Control a gradual, albeit overlapping transition from costing focussed to budgeting focussed discourse is certainly reflected in the accounting and business books and articles of the 1930s and 1940s (Parker, 1986a). Furthermore Parker's (2002) study of $20^{\text {th }}$ century textbook budgetary discourse reveals a major focus on the development of corporate budgeting in the 1930s and on into the 1940s. It represented a watershed period in the development of contemporary principles and approaches to corporate budgeting, ranging across the advocacy and discussion of planning versus forecasting, the approach to target setting, the nature of control, the role of budgets in coordination, budgetary process advantages and disadvantages and issues of budgetary implementation. These concerns were debated across accounting, business and management literatures of the period, so that arguably the gradual disappearance of 'scientific costing' may have reflected the cost accounting profession's adoption of 'budgetary planning and control' as the new dominant language and focus of business. In this sense the ICWA too, may have moved on to embrace concepts and language it identified as more closely aligned to changing business norms and practices. This may have been a process of transmutation between scientific costing and budgeting discourse. Thus when one of the leading figures in the ICWA, Dunkerley, used the phrase 'scientific costing' once again in the early 1930s, he did so in the context of discussing budgetary control as he moved into an advocacy of its practice in the UK setting (Dunkerley, 1931).

So the subsuming of standard costing within a budgetary planning and control framework, both conceptually and as the language of business, appears to have rendered notions of scientific costing somewhat obsolete, or at least of less unique potential brand value than previously when costing was arguably king. Of course costing was still an important part of ICWA members' focal functions and identification, but the beginnings of a move towards their involvement in budgeting and standard costing, expanded the scope of their services so that any focus on or major identification with scientific costing risked narrowing their branding identification and appeal to employers and organisational management. So the context surrounding the ICWA post Charter application failure exhibited a 'new' focal practice set and related nomenclature that arguably became a dominant symbol for cost and management accounting through much of the remainder of the $20^{\text {th }}$ century. In the changed external business focus, and well aware of this new legitimising discourse that embodied costing standards and efficiency ${ }^{21}$, the new leaders of the ICWA from 1924 helped to engineer a move away from an identification of the organisation with 'scientific costing'. No longer did this particular form of language and related branding serve their agenda of legitimising their focal practices of cost accounting or serve their ambitions to control and dominate that field of practice for their own status and economic self-interest (Habermas, 1990; Kosmala, 2005).

\section{Lessons for professional branding strategy}

Arguably, in contemporary parlance, the ICWA's adoption of the phrase 'scientific costing' constituted a branding strategy. Branding involves attempting to create a unique organisational and/or product identity and personality that will attract and retain its target market. While products and services may change, the notion of a brand attempts to secure 
a continuity of target stakeholders' positive perceptions and identification over time (Saunders and Watters, 1993). Brands can be employed to communicate desired messages about organisational cultural characteristics, values and differential status, thereby projecting imagery about how the organisation and its services would like to be seen, in the hope of attracting approval and loyalty (Jones, 1994; Casson, 1994). They variously transmit messages concerning organisational and service attributes, images, experiences, attitudes and benefits that all attempt to build brand knowledge amongst the target audience (Keller, 2003). In doing so, branding appeals to target audience imagination, self-esteem, social acceptance and social status aspirations (Casson, 1994). Of course there are considerable differences in focus and implementation between branding an organisation or selections from its products and services. Arguably the ICWA was adopting something of a dual branding strategy in the early 1920s. Hence, the emphasis on 'scientific costing' while significant as a strategy in itself, also constituted part of a broader strategy based around the growing association of costing with science, attempting to create a high quality, high status brand that would enhance its prospects of public and professional recognition. In one sense, the ICWA uptake of scientific methods and 'scientific costing' as high profile terminologies, resembled ingredient branding whereby a manufacturer promotes a particular ingredient in its product(s) to the target market (Norris, 1992).

However, particularly in the financial services industry, there are limits to the potential effectiveness of branding strategies. Research suggests that very few brands in this industry can achieve significant differentiation from their competitors, especially given the relative intangibility of services provided (Papasolomou and Vrontis, 2006). Additionally, market research has demonstrated that branding has been found to have limited utility for projecting an image of quality which is more susceptible to demonstrated actual service quality experiences rather than projected imagery (Casson, 1994; Saunders and Watters, 1993). Furthermore, with respect to any suggestion that 'scientific costing' might have been a successful ingredient branding strategy, Norris (1992) argues that ingredient branding requires the ingredient to be absolutely critical to the success of the end-product services for any significant branding campaign impact, and that it risks only short term versus longer term target market impact as well as potential market confusion if competitors are seen to command similar ingredients anyway. In addition, empirical market research suggests that a self-branded ingredient branding strategy where the organisation promotes its own particular ingredient selfbrand, the short and longer term brand equity of the host brand is not greatly enhanced. This may be due to the host brand lacking credibility (Desai and Keller, 2002). Thus the 'scientific costing' promotion may have had limited prospects of distinguishing perceptions of the ICWA itself from competitor accounting bodies, or even for developing status imagery that could equate with them.

One final complication in an ICWA strategy of brand enhancement via 'scientific costing' lay in the distinction (or lack thereof) between the ICWA organisation and its professional culture represented by such terminology as 'scientific costing'. Contemporary consumer research suggests that the target market's knowledge of the organisation itself can have significant implications for its reaction to any branding, 
especially of organisational products and services. This reflects Ashcraft, Muhr, Rennstam and Sullivan's (2012) recognition that collective identity branding reflects the participation and reactions of multiple stakeholders and not just a professional association imposing its brand on passive consumers. A positive organisational reputation could leverage related services and their branding, while on the other hand, any limitations to organisational reputation may not be overcome by services branding exercises (Keller, 2003). This is particularly pertinent to the accounting profession where consumers may experience difficulty in judging the quality of accounting services. Hence the image of the organisation may overwhelm any attempt at a particular service based branding strategy. This is held to be particularly so in the financial services industry where the target market may develop clear perceptions of the organisation but not of its specific services or style of services which may be simply viewed as components of the overall organisational brand (de Chernatony and Riley, 1999). Similarly for the accounting profession, as Richardson and Jones (2007) contend, service is often chosen on the basis of organisational or individual reputation. Thus as an historical equivalent of a contemporary branding strategy, the ICWA's promotion of 'scientific costing' rhetoric in the early 1920s appears to have had limited prospects for enhancing the ICWA's own status and professional recognition, despite the support from some prominent industrialists. The limited accumulated reputation of the association as a whole, most likely dominated peer professional and public perceptions.

Thus 'scientific costing' as a service or ingredient branding strategy, faced significant barriers in attempting to enhance the existing ICWA organisational brand as a professional body. While attempting to invoke a societal fascination with scientism, it nonetheless faced limits to its potential impact upon overall ICWA profile given the already established prejudices against cost accountants. It ran up against the culturalcognitive frames of reference that excluded cost accounting from the high status definitions of what constituted the accepted accounting skill set. The chances of branding via 'scientific costing' being an effective form of advocacy and winning target stakeholder support, was therefore limited by stakeholders' prejudices against the scope of work and status claimed by the ICWA.

It seems that the problems with the use of 'scientific costing' as a branding strategy were recognised within the ICWA itself. Disagreements over the meaning of the term amongst members of the ICWA's council, witness the differing views expressed by Todman and Stelling, may explain why the term 'scientific costing' was omitted from the Royal Charter bid in 1923. Despite this, the bid document nevertheless stressed the fact that modern cost systems were scientific, indicating the broader importance of the link between science and costing as part of the campaign to enhance the status of cost accountants.

\section{Conclusion}

Language is one of the symbols of authority over a field of expertise which can be employed by an association in its professionalization process. As Greenwood (1966: 17) has pointed out, as 'meaning-laden items', such symbols must have substance, reflecting 
association philosophies and performance, if they are to legitimise identity, status and control over an occupational domain. If external stakeholders do not accept such symbols, then an association's claims are likely to fail (Barber, 1965; Willmott, 1986; Birkett and Evans, 2005). In this paper we have examined the changing discourse around accounting, cost calculation and science between c. 1890 and c.1930. In the course of this study, we have identified the short-lived use of the term 'scientific costing' from 1919 to 1924 and suggested that its employment was part of the discourse and rhetoric surrounding the ICWA's pursuit of public and professional recognition and status, reflecting that such discourse can form part of a profession's survival and growth strategy (Covaleski, Dirsmith and Rittenberg, 2003). The ICWA attempted to construct a symbolic image of esoteric and intangible systems of knowledge over which it claimed its members alone were capable of exercising mystical power. To this end, the term 'scientific costing' was, for a period, employed to mimic the growing social and business popularity of scientific management, thereby attempting to enhance the status and institutionalisation of the cost accounting profession. However, its currency was short-lived, and it fell from favour as an ICWA professionalizing strategy.

In this historical case, we find clear evidence of the employment of language in search of power and control over both institutional structures and processes in the shape of cost accounting practices and an identifiable and recognised accounting body to dominate them (Habermas, 1990; Prasad, 2002; Kosmala, 2005). However instead of the rise and dominance of a form of language, this historical episode reveals a more evident uptake of language as a weapon in the attempt to draw the boundaries around a field of practice and then to dominate and control its operation. While presented as a technical phenomenon, it in fact connoted an underlying strategy of aligning cost accounting with an apparent societal attraction to the scientific way. When this alignment was found wanting, the apparent strategic role of scientific costing language was revealed for what it was, and it rapidly disappeared from the cost accounting lexicon.

The ICWA 'scientific costing' case illustrates the limitations of organisations' ill-judged or ill-timed attempts to mobilise ingredient branding strategies. The association of a 'scientific costing' brand with the scientific management brand was doomed to failure when the latter came under criticism and fell from favour in the British business environment (Keller, 2003). Furthermore a brand such as 'scientific costing' nonetheless suffered the general intangibility of financial services (Papasolomou and Vrontis, 2006) and faced the hurdle of attempting to overcome the already developed branding (and other professional associations' resistance to it) of the organisation (the ICWA) itself. Thus a specific ingredient or strategy branding exercise by a professional body can be conditioned by a number of salient factors in its institutional and societal environment. Such professional association branding issues still have considerable currency today. In recent years, the accounting profession has seen the emergence of intra-profession competition, with national and international professional accounting bodies facing ongoing challenges to recruitment and retention of accounting graduates. In this competitive environment, Inglis, Shelley, Morely and Delange (2011) found brand to be an important member attraction strategy for professional accounting bodies. In recent 
years, in vying with one another to attract new members, the professional accounting bodies have re-examined and, in some cases, attempted to refresh their brand image.

Of the seven United Kingdom (UK)/Republic of Ireland (ROI) accountancy bodies overseen by the Financial Reporting Council in 2015, the ICAEW, with 123,541 members in the UK/ROI, while accounting for slightly more than a third of the UK/ROI total membership of these bodies, only accounted for a smaller proportion $(29.3 \%)$ of their total worldwide membership (ACCA being the largest with a worldwide membership of 183,386, against the ICAEW's 145,746). ${ }^{22}$ Thus, in its 2015 annual review, the ICAEW (2016: 19) referred to one of its three strategic objectives as having been support for the chartered accountant brand. It stressed the importance of building the Institute's brand profile and reputation, it being noted that the Institute had carried out a " $360^{\circ}$ brand review" and run "several brand promotion campaigns" (ICAEW, 2016: 19). In part, this action was a response to developments undertaken by other professional accounting bodies, including the joint venture partnership formed between CIMA and AICPA in 2011, which established the designation of Chartered Global Management Accountant (CGMA) in 2012. The importance of having a differentiated brand is clearly seen as important for CIMA. As DeSantis and Breindel (2018) have indicated, there is a need for professional bodies to develop "positioning through a 'brand voice", organisations need a brand strategy. These actions in the 2010s, however, are not the first, and no doubt will not be the last, attempts to forge principles and create brands within the area of management accounting. In this study we have examined the attempt by CIMA's forerunner, the ICWA, to develop a brand image during the 1920s. While some of the problems it faced were due to the historical context, there are lessons which can be drawn from such an analysis for modern organisations seeking to establish their 'brand voice'.

\section{Notes}

1. The ICWA was incorporated as a company limited by guarantee on 8 March 1919 as the Institute of Cost Accountants Ltd. (Loft, 1990: 29). Loft (1990: 34) notes that it was resolved on 29 April 1919 to change the name to ICWA but that the change took some time to effect.

2. Given the emphasis within this paper on the changing use of language over the study period, we are reluctant to impose on our analysis the use of a particular phrase, such as cost accounting (as used by Loft), that was current at the time and has subsequently received general acceptance. Thus we will use the more neutral phrase 'cost calculation' to represent the work carried out by those who sought a greater role for the calculation of costs between c. 1890 and c. 1930 .

3. Each work ran to multiple editions: the seventh edition of Factory Accounts was published in 1922 and the fifth edition of Norton's text in 1931. Although the precise (and somewhat long-winded) title of the former changed over the years, neither the term cost nor costing ever appeared in it, but in the last edition of Norton's work, which was divided into two parts, the second part was entitled 'Cost accounting and cost control'.

4. The journal first appeared in October 1874 as a monthly journal, becoming weekly from 2 January 1875.

5. Prior to 1890 , the only index references were to the cost-book system used in mining enterprises, and a few such references continued into the 1890 s and beyond. During the 
period 1890-1900 inclusive, there were 14 references to 'cost' or 'costs' (excluding those such as 'cost of officialdom', 'costs of compulsory liquidation', etc.), seventeen to 'cost accounts' (13 of which occurred in 1894 alone) and 10 to 'costing'. Of the latter, nine occurred in 1892 (the other in 1900), apparently as an editorial response to the paper on 'Manufacturing Costs' by Plumpton (1892).

6. In the USA 'costing' was much less widely used, preference being given to 'cost accounting'.

7. COPAC (http://copac.ac.uk) is a database which merges together the catalogues of all major British libraries, comprising major copyright libraries such as the British Library and the National Libraries of Scotland and Wales, together with the libraries of the major British universities, including Oxford and Cambridge, plus many others.

8. Worldcat (www.worldcat.org) is a database which contains 54.1 million holdings from libraries all over the world.

9. Before WWI Preen (1907: 65) had used the phrase "scientific costings".

10. Jenkinson was a chartered accountant who became Director of Factory Accounting at the Ministry of Munitions during WWI (Davenport-Hines, 1985: 484). However, in his paper, Jenkinson (1919) did not use the term 'scientific costing', though he talked about "scientific management", "the science of industrial administration", "a properly devised costing system" and standardised, i.e. uniform, costing as introduced during WWI at factories under the control of the Ministry of Munitions. He also linked scientific management and costing thus (Jenkinson, 1919: 188):

"Can it be denied ... that scientific management based on ascertained facts and figures is a force which must improve the conditions of labour?

"The worker has a very direct interest in efficient costing."

11. The reason for the use of this heading was probably that Sambidge's letter was written on ICA headed notepaper, despite the fact that a resolution to change the name had been made at the end of April (see note 1 above).

12. It is perhaps of some relevance that work on preparing this paper is likely to have been undertaken during the period of eight months during 1921-22 when Todman relinquished chairmanship of the ICWA's executive committee (Loft, 1990: 54).

13. Nothing is known about Whitehouse, who was not a member of the ICWA, but Griffiths was one of the first FCWAs, being admitted in June 1919 (ICWA, 1923). However, he only became involved in the ICWA's Council after the re-organisation of 1924 (he subsequently became Honorary Treasurer in 1938) (ICWA, 1938). Gill became an FCWA in January 1921 (ICWA, 1923) and was an active contributor of papers to The Cost Accountant in the 1920s. Like Griffiths, he was not a member of Council before 1924, but in 1928 he is listed as the chair of Council (ICWA, 1928).

14. Roland Dunkerley had become an FCWA in March 1920 and a member of Council in July 1920 (ICWA, 1923; Loft, 1990: 54). He became chair of ICWA's Council in 192324 (The Cost Accountant July 1923: 49), the period of structural reorganisation of the institute, was Honorary Secretary from at least 1928 through to 1933 (ICWA 1928; 1933) and was president of ICWA in 1933-34 (ICWA 1935). In later years he began to emphasise the practical nature of costing: thus in his presidential address to the $12^{\text {th }}$ ICWA costing conference he stated that "costing is not a science where definite rules can be written down and followed blindly" (Dunkerley, 1933: 430) and ten years later noted that "cost accounting ... deals in facts not theories" (Dunkerley, 1944: 54). Dunkerley was the first recipient of the ICWA's Gold Medal in 1955 (The Cost Accountant, 1955).

15. At the time of ICWA's formation they were both employed by A.W. Lyon \& Co. Ltd., subsequently forming their own business, Todman, Ryall \& Co. Ltd. in 1920 (Loft, 1990: 81). The headquarters of the ICWA were in premises shared with Todman, Ryall \& Co. Ltd. in the early years (Loft, 1990: 56).

16. Frustrated by lack of action within the ICWA. Ryall published the first edition of his own costing dictionary in 1926 but it too made no reference to 'scientific costing' (Ryall, 1926). 
17. The other chartered bodies which objected were the Royal Institute of British Architects, the Institute of Chemistry and the Chartered Institute of Secretaries. One non-chartered accountancy body, the Society of Incorporated Accountants and Actuaries, also lodged a counter-petition.

18. By 1928, Russell had become Honorary Treasurer of ICWA and retained this position through until 1937/8 when his place was taken by P. Griffiths (ICWA, 1928; 1938). Russell became president of ICWA and chair of its Council in 1938-39 (The Cost Accountant 1946-47).

19. It also seems to have provided greater freedom and opportunities for Ryall, who wrote two significant works shortly after leaving ICWA's Council: Primer of Costing, published in 1925 and Dictionary of Costing published in 1926.

20. This may also explain why the title of the first British text on scientific management (McKillop and McKillop, 1917) was changed from Efficiency Methods: An Introduction to Scientific Management to A Special Report on Costing and Production Methods That Reduce Costs, when it was re-issued in 1928, despite the contents of the book being unchanged. It is also possible that the change may have been due to legal issues since the book was re-issued by A.W. Shaw \& Co. rather than by the original publishers, George Routledge \& Sons Ltd.

21. A key figure in both the ICWA and the budgeting movement was Roland Dunkerley. He gained initial experience of budgetary control and standard costing at Hans Renold Ltd. before leaving the company in 1920 to take up the role of works accountant with Metropolitan-Vickers Electrical Co. Ltd. In 1928 he joined the United Steel Companies Ltd. where he helped introduce standard costing and budgetary control (Manchester Central Library: M501 920 DR 95/1; Boyns, 1998).

22. The figures relate to full members and do not include students: worldwide, ACCA had 388,636 students compared to the ICAEW's 24,149 (Financial Reporting Council: Key Facts \& Trends in the Accountancy Profession, 2015, pp. 10-11.

\section{Acknowledgements}

This paper's development has benefited from the critical comments and advice received from colleagues at presentations made at the Universities of Glasgow, Edinburgh, Dundee, La Trobe University (Melbourne), and Auckland University (New Zealand) and as an invited plenary paper to the University of New South Wales Management Accounting Research Colloquium. We are also indebted to critical advice provided by Professors Lisa Evans (Stirling University), Kerry Jacobs (UNSW Canberra), John Burns (University of Exeter), Jim Haslam (Heriot Watt University), Wai Fong Chua (University of New South Wales), Jan Mouritsen (Copenhagen Business School), Ken Shackleton, John Holland, John McKernan, Clive Emmanuel, and John Eldridge (Glasgow University), Ian Thompson (University of Strathclyde), Ingrid Jeacle (University of Edinburgh), Larry O'Connor (La Trobe University) and Steve Walker (University of Edinburgh). We are also grateful to BAR's anonymous reviewers for their constructive and valuable advice.

\section{Bibliography}

Primary sources 
Manchester Central Library: M501 920 DR 95/1 Biography of the career to 1935 of Roland Dunkerley.

TNA - The National Archives, Kew, London: PC12/30 - folders 128078 (ICWA Petition 1923), folder 128274 (Counter petitions), folder 128335 (ICWA's response to counter-petitions) and folder 128514 (letters/memos from Government Actuary and Board of Trade; decision of Privy Council, etc.).

Secondary sources

Ashcraft, K.L., Muhr, S.L., Rennstam, J. and Sullivan, K. (2012). Professionalization as a branding activity: occupational identity and the dialectic of inclusivity-exclusivity. Gender, Work and Organization, 19(5), 467-488.

Atkinson, R.F. (1978). Knowledge and Explanation in History: an Introduction to the Philosophy. London: Macmillan Press.

Banyard, C.W. (1985). The Institute of Cost and Management Accountants - a History. London: ICMA.

Barber, B. (1965). Some problems in the sociology of the professions. In K.S. Lynn (ed.), The Professions in America (pp. 15-34). Boston: Houghton Mifflin Company.

Bardsley, J.B. (1902). Hints to students in devising systems of engineers' cost accounts. The Accountant, 28, 1053-1061.

Barzun, J. and Graff, H.F. (1985). The Modern Researcher. New York: Harcourt Brace Jovanovich.

Bedeian, A.G. (1998). Exploring the past. Journal of Management History, 4(1), 4-15.

Belkaoui, A. (1990). Judgement in International Accounting. New York: Quorum Books.

Benders, J. and Van Veen, K. (2001). What's in a fashion? Interpretative viability and management fashions. Organization, 8(1), 33-53.

Bird, C.F. (1921). Costing - principles and practice. The Accountant, 65, 745-748.

Birkett, W.P. and Evans, E. (2005). Theorising professionalization: a model for organising and understanding histories of the professionalising activities of occupational associations of accountants. Accounting History, 10(1), 99-127.

Boland, R.J. (1993).Accounting and the interpretive act. Accounting, Organizations and Society, 18(2-3), 125-146.

Boyns, T. (1998). Budgets and budgetary control in British businesses to c.1945. Accounting, Business and Financial History, 8(3), 261-301.

Boyns, T. (2003). In memoriam: Alexander Hamilton Church's system of 'scientific machine rates’ at Hans Renold Ltd., c.1901-c.1920. The Accounting Historians Journal, 30(1): 3-44. 
Boyns, T. and Edwards, J.R. (2013). A History of Management Accounting: the British Experience. New York and London: Routledge.

Bronowski, J. and Mazlish, B. (1960). The Western Intellectual Tradition: from Leonardo to Hegel. London: Hutchinson.

Burton, F.G. (1912). Cost accounts. The Accountant, 46, 324-331.

Campbell, N.R. (1919). Physics, the Elements. Cambridge: Cambridge University Press.

Carson, P.P., Lanier, P.A., Carson, K.D. and Birkenmeier, B.J. (1999). A historical perspective on fad adoption and abandonment. Journal of Management History, 5(6), 320-333.

Carter, R.N. (1923). Advanced Accounts. London: Pitman.

Casson, M. (1994). Economic ideology and consumer society. In G. Jones and N.J. Morgan (eds.), Adding Value: Brands and Marketing in Food and Drink (pp. 41-58). London: Routledge.

Cathles, A. (1920). The general principles of costing. The Accountant, 62, 249-256.

Chambers, R.J. (1995). An Accounting Thesaurus - 500 years of Accounting. Oxford: Elsevier Science Ltd.

Child, J. (1969). British Management Thought: A Critical Analysis. London: Allen \& Unwin.

von Colbe, W.B. (1996). Accounting and the business economics tradition in Germany. The European Accounting Review, 5(3), 413-434.

Cole, W.M. (1908). Accounts, Their Construction and Interpretation. Boston: Houghton Mifflin.

Covaleski, M.A., Dirsmith, M.W. and Rittenberg, L. (2003). Jurisdictional disputes over professional work: the institutionalization of the global knowledge expert. Accounting, Organizations and Society, 28(4), 323-355.

Craggs, G.S. (1915). Manufacturing costs. The Accountant, 52, 756-766.

Davenport-Hines, R.P.T. (1985). Sir Mark Webster Jenkinson (1880-1935): accountant and industrialist. In D.J. Jeremy (ed.), Dictionary of Business Biography, vol. III (H-L) (pp. 483-490). London: Butterworths.

Dent, A.G.H. (1935). Management Planning and Control. London: Gee \& Co.

De Paula, F.R.M. (1948). Developments in Accounting. London: Sir Isaac Pitman \& Sons, Ltd.

De Chernatony, L. and Riley, F.D. (1999). Experts' views about defining services brands and the principles of services branding. Journal of Business Research, 46, 181-192.

De Saussure, F. (1966). Course in General Linguistics. New York: The Philosophical Library. 
Desai, K.K. and Keller, K.L. (2002). The effects of ingredient branding strategies on host brand extendibility. The Journal of Marketing, 66(1), 73-93.

DeSantis and Breindel (2018). Cutting through the Sea of Sameness: Creating a Stand-Out Law Firm Brand', https://www.desantisbreindel.com/wp-content/uploads/DB-WhitepaperLawFirmBranding-R4.pdf , p.6. (Accessed 29 May 2018).

Dilthey, W. (1976). Selected Writings (H.P. Rickman ed.) Cambridge: Cambridge University Press.

Duncan, J.C. (1909). A definition of accounting. American Economic Association Quarterly, $3^{\text {rd }}$ series, 10, April, 75-84.

Dunkerley, R. (1928). The influence of cost accounting on the management of a manufacturing concern. The Cost Accountant, 7, 281-287.

Dunkerley, R. (1931). The cost accountant of to-morrow. The Cost Accountant, 10, 343-344.

Dunkerley, R. (1933). ICWA Presidential address. National Association of Cost Accountants

Bulletin, 15(7), 421-431.

Dunkerley, R. (1944). Cost accountancy: its contribution to management and efficiency in the future. The Cost Accountant, 23, 52-57.

Edwards, R.S. (1937). Some notes on the early literature and development of cost accounting in Britain. The Accountant, 96; 193-195, 225-231, 253-255, 283-287, 313-316, 343-344.

Elbourne, E.T. (1915). Approximation in factory accounting. The Accountant, 52, 388-396.

Elton, G.R. (1967). The Practice of History. Glasgow: Collins, Fontana.

Evans, J.J. (1923). Principles of scientific costing. The Cost Accountant, 3, 251.

Evans, L. (2004). Language, translation and the problem of international accounting communication. Accounting, Auditing \& Accountability Journal, 17(2), 210-248.

Ewing, F. (1923). The connection between costs and financial accounts. The Cost Accountant, 3, 42-44.

Fells, J.M. (1907). The new accountancy. The Incorporated Accountants' Journal, May, 195-198.

Fells, J.M. (1910). The accountancy of to-morrow. The Incorporated Accountants' Journal, December, 69-72.

Fells, J.M. (1919). Some principles governing the ascertainment of cost. The Incorporated Accountants' Journal, November, 31-34.

Financial Reporting Council (2016). Key Facts \& Trends in the Accountancy Profession, 2015. Retrieved August 28, 2018, from https://www.frc.org.uk/getattachment/cd51413b-df19-4ca58a58-e51a9a735772/2016-KFAT.pdf 
Fleischman, R. (2009). Management accounting: theory and practice. In J.R. Edwards and S. P Walker (eds), The Routledge Companion to Accounting History (pp. 189-223). London: Routledge.

Fleming, A.I.M., McKinstry, S., and Wallace, K. (2000). Cost accounting in the shipbuilding, engineering and metals industries of the West of Scotland, 'The Workshop of the Empire', c. 1900 - 1960. Accounting and Business Research, 30(3), 195 - 211.

Foster, B.F. (1837). A Concise Treatise on Commercial Book-keeping. Boston: Perkins \& Marvin; Philadelphia: H. Perkins.

Foster, B.F. (1843). Double Entry Elucidated. London: Souter and Law.

Garner, S.P. (1954). The Evolution of Cost Accounting to 1925. Alabama: University of Alabama Press.

Gill, S.L. (1923a). The place of the cost accountant in industry. The Cost Accountant, 2, 331-339.

Gill, S.L. (1923b). Are costs the best basis for estimating and fixing selling prices? The Cost Accountant, 2, 425-428.

Gill, S.L. (1925a). Cost accounting and modern management. The Cost Accountant, 4, 366-375.

Gill, S.L. (1925b). Cost accounting and new requirements in business. The Cost Accountant, 5, 62-68.

Gill, S.L. (1927-8). The cost accountant and factors in efficiency. The Cost Accountant, 7, 233240.

Goode, G.E. (1900). The methods of ascertaining costs in a factory where a variety of articles are made, which mostly pass through several processes in the course of manufacture and are turned out in large quantities. The Accountant, 26, 600-607.

Greenwood, E. (1966). The elements of professionalization, In H.M. Vollmer and D.L. Mills (Eds.), Professionalization (pp. 9-19). Englewood Cliffs, NJ: Prentice-Hall.

Griffiths, P. (1923). Industrial economics from a cost accountant's point of view. The Cost Accountant, 2, 295-298.

Griffiths, P. (1929). Cost accounting as a factor in business economics. The Cost Accountant, 8, 284-287.

Gyarmati, G. K. (1975). The doctrine of the professions: basis of a power structure. International Social Science Journal, 27(4), 629-654.

Habermas, J. (1984). The Theory of Communicative Action. In T. McCarthy Trans. Boston: Beacon; 1.

Habermas, J. (1987). The Theory of Communicative Action. In T. McCarthy Trans. Boston: Beacon; 2. 
Habermas, J. (1990). A review of Gadamer's “Truth and Method”. In G.L. Ormiston and A.D. Schrift (Eds.), The Hermeneutic Tradition: from Ast to Ricoeur (pp. 213-244). Albany, NY: SUNY Press.

Haskins, C.W. (1900). Accountancy. The Accountant, 26, 1010-1014.

Hernandez Esteve, E. (2003). Accounting as a science: the origins of the concept in Spain (18001950). Paper presented at $3^{\text {rd }}$ Accounting History conference, Siena, Italy, September.

ICAEW. (2016). Building the Accountancy Profession of the Future. Annual Review 2015. Retrieved September 26, 2016, from, https://www.icaew.com//media/corporate/archive/files/about-icaew/what-we-do/annual-review/2015/icaew-annualreview-2015.ashx?la=en

ICWA. (1923). Institute of Cost \& Works Accountants Year book, 1923, London: Author.

ICWA. (1928). Institute of Cost \& Works Accountants List of members, 1928, London: Author.

ICWA. (1933). Institute of Cost \& Works Accountants List of members, 1933, London: Author.

ICWA. (1935). Institute of Cost \& Works Accountants List of members, 1935, London: Author.

ICWA. (1938). Institute of Cost \& Works Accountants List of members, 1938, London: Author.

Inglis, R., Shelley, M., Morely, C. and Delange, P. (2011). A collective, undifferentiated accounting profession: An Australian study. Accounting \& Finance, 51(3), 711-731.

Jackson, W. (1809). Bookkeeping in the True Italian Form. Dublin: Fitzpatrick and others.

Jenkins, H.G. (1922). The planning of finance. The Cost Accountant, 2, 82-84.

Jenkinson, M.W. (1907). Cost accounts for small manufacturers. The Accountant, 34, 315-326 and 351-359.

Jenkinson, M.W. (1914). Some principles of accounting affecting cost accounts. The Accountant, 50, 564-582.

Jenkinson, M.W. (1919). The workers' interest in costing. The Accountant, 60, 185-195.

Jones, G. (1994). Brands and marketing. In G. Jones and N.J. Morgan (Eds.), Adding Value: Brands and Marketing in Food and Drink (pp. 1-12). London: Routledge.

Keller, K.L. (2003). Brand synthesis: The multidimensionality of brand knowledge. Journal of Consumer Research, 29, 595-600.

Kirkaldy, A.W. (1925). The need for scientific costing in modern business. The Cost Accountant, 4, 375-376.

Kosmala, K. (2005). Insights from Ricoeur's hermeneutics on best practice in professional service firms: on perpetual myth creation? Qualitative Sociology Review, 1(1), 31-50. 
Leff, G. (1971). History and Social Theory. Garden City, New York: Anchor Books, Doubleday \& Co. Inc.

Lisle, G. (1899). Accounting in Theory and Practice. Edinburgh: Green.

Llewellyn, S. (1993). Working in hermeneutic circles in management and accounting research: some implications and applications. Management Accounting Research, 4(3), 231-249.

Locke, R.R. (1979). Cost accounting an institutional yardstick for measuring British entrepreneural performance, circa 1914. The Accounting Historians Journal, 6(2), 1-22.

Loft, A. (1986). Towards a critical understanding of accounting: the case of cost accounting in the UK, 1914-1925. Accounting, Organizations and Society, 11(2), 137-169.

Loft, A. (1990). Coming into the Light: A Study of the Development of a Professional Association for Cost Accountants in Britain in the Wake of the First World War. London: Chartered Institute of Management Accountants.

Mann, J. Jr. (1978). Oncosts or expenses. In Encyclopaedia of Accounting, vol. V, 1903 reprinted in R.P. Brief (Ed.), Selections from Encyclopaedia of Accounting (pp. 231-258). New York: Arno Press.

Marriner, S. (1980). The Ministry of Munitions 1915-1919 and government accounting procedures. Accounting and Business Research, 10(37A), 130-142.

Massey, J.R. (1919). The relationship of costing to management. The Accountant, 61, 12-17.

Mattessich, R. (2008). Two Hundred Years of Accounting Research. London \& New York: Routledge.

McKillop, M.A. and McKillop, A.D. (1917). Efficiency Methods - An Introduction to Scientific Management. London: George Routledge \& Sons.

McKinstry, S. (1999). Engineering culture and accounting development at Albion Motors, 1900 - . 1970. Accounting, Business and Financial History, 9(2), 203 - 223.

McLean, T. (1995). Contract accounting and costing in the Sunderland shipbuilding industry, 1818-1917. Accounting, Business and Financial History, 5(1): 109-145.

McLean, T. (2013). Cost engineering and costing in Hawthorn Leslie Shipbuilders, 1886 - 1915. The British Accounting Review, 45(4), 284-296.

McLean, T., McGovern, T. and Davie, S. (2015). Management accounting, engineering and the management of company growth: Clarke Chapman, 1864 - 1914. The British Accounting Review, 47(2), 177-190.

McMillan, K.P. (1998). The science of accounts: bookkeeping rooted in the ideal of science. Accounting Historians Journal, 25 (Dec.), 1-33. 
McMillan, K.P. (1999). The Institute of Accounts: a community of the competent. Accounting. Business \& Financial History, 9(1), 7-28.

Medawar, P.B. (1986). The Limits of Science. Oxford: Oxford University Press.

Miller, P. (1998). The margins of accounting. The European Accounting Review, 7(4), 605-621.

Miller, P. and Napier, C. (1993). Genealogies of calculation. Accounting, Organizations and Society, 18(7/8), 631-647.

Morgan, G. (1986), Images of Organization. Newbury Park, CA: Sage.

Napier, C.J. (1996). Academic disdain? Economists and accounting in Britain, 1850-1950. Accounting, Business \& Financial History, 6(3), 427-450.

National Industrial Conference Board. (1931). Budgetary Control in Manufacturing Industry. New York: National Industrial Conference Board, Inc.

Norris, D.G. (1992). Ingredient branding: a strategy option with multiple beneficiaries. Journal of consumer marketing, 9(3), 19-31.

North, R. (1714). The Gentleman Accomptant. London: Curll.

Papasolomou, I. and Vrontis, D. (2006). Building corporate branding through internal marketing: the case of the UK retail bank industry. Journal of Product and Brand Management, 15(1), 37-47.

Parker, L.D. (1986a). Developing Control Concepts in the 20th Century. New York: Garland Publications.

Parker, L.D. (1986b). The classical model of control in the accounting literature. The Accounting Historians Journal, 13(1), 71-92.

Parker, L.D. (1999). Historiography for the new millennium: adventures in accounting and management. Accounting History, 4(2), 11-42.

Parker, L.D. (2002). $20^{\text {th }}$ Century textbook budgetary discourse: formalisation, normalisation and rebuttal in an anglo-saxon environment. European Accounting Review, 11(2), 305-327.

Parker, L. D. \& Ritson, P. A. (2011a), Accounting's latent classicism: revisiting classical management origins. Abacus, 47(2), 234-265.

Parker, L \& Ritson, PA (2011b), Rage, rage against the dying of the light: Lyndall Urwick's scientific management. Journal of Management History, 17(4), 379-398.

Parker, R.H. (1994). Finding English words to talk about accounting concepts. Accounting, Auditing and Accountability Journal, 7(2), 70-85.

Paton, W.A. and Stevenson, R.A. (1917). Principles of Accounting. Ann Arbor: Wahr.

Pearson, K. (1911). The Grammar of Science. London: Black. 
Perry-Keene, L.A. (1922-23). Cost control in the motor car and allied industries. The Cost Accountant, 2, 104-107, 132-138, 170-174, 220-224, 252-256 and 284-285.

Perry-Keene, L.A. (1925). Budgetary control. The Cost Accountant, 4, 402-406.

Plumpton, T. (1892). Manufacturing costs. The Accountant, 18, 267-271.

Prasad, A. (2002). The contest over meaning: hermeneutics as an interpretive methodology for understanding texts. Organizational Research Methods, 5(1), 12-33.

Previts, G.J., Parker, L.D. and Coffman, E.N. (1990). Accounting history: definition and relevance. Abacus, 26(1), 1-15.

Preen, H. (1907). Reorganisation and Costings: a Book for Manufacturers and Merchants. London: Simpkin, Marshall, Hamilton, Kent \& Co.

Preen, H. (c.1909). Falling Sales Yet Increased Profits. London: Simpkin, Marshall, Hamilton, Kent \& Co.

Quennell, F.T. (1925). Budgetary control. The Cost Accountant, 4, 407-412.

Richardson, A.J. and Jones, D.G. (2007). Professional "brand", personal identity and resistance to change in the Canadian accounting profession: a comparative history of two accounting association merger negotiations. Accounting History, 12(2), 135-164.

Ritson, P. A. and Parker, L.D. (2016). You're in the army now! Historical lessons for contemporary management theorists. Journal of Management History, 22(3), 320-340.

Robson, K., Willmott, H., Cooper, D. and Puxty, T. (1994). The ideology of professional regulation and the markets for accounting labour: three episodes in the recent history of the U.K. accountancy profession. Accounting, Organizations and Society, 19(6), 527-553.

Ryall, R.J.H. (1926). Dictionary of Costing. London: Sir. I. Pitman \& Sons.

Saunders, J. and Watters, R. (1993). Branding financial services. International Journal of Bank Marketing, 11(6), 32-38.

Schleiermacher, F.D.E. (1985). Selections from hermeneutics: the handwritten manuscripts of F.D.E. Schleiermacher. In K. Mueller-Vollmer (Ed.), The Hermeneutic Reader (pp. 73-97). New York: Continuum.

Sewell, G. and Wilkinson, B. (1992), Someone to watch over me: surveillance, discipline and the just-in-time labour process, Sociology, 26( 2), 271-289.

Showell, A.E. (1901). Cost accounts. The Incorporated Accountants' Journal, December, 59-64.

Smith, A. (1912). The abuse of the audit in selling securities. Journal of Accountancy, October, 243-253.

Solomons. D. (1952). The historical development of costing. In D. Solomons (Ed.), Studies in Costing (pp. 1-52). London: Sweet \& Maxwell. 
Sombart, W. (1902). Der moderne kapitalismus, vol II. Leipzig: Duncker and Humblot.

Spencer, H. (1861). Essays on Education and Kindred Subjects. London: Dent.

Stanford, M. (1998). An Introduction to the Philosophy of History. Blackwell: Massachusetts.

Stelling, R. (1924). Standard costs, with particular reference to the Sheffield industries. The Cost Accountant, 3, 277-281.

The Accountant. (1894). Cost accounts. - I. The Accountant, 20, 655-657.

The Accountant. (1919a). Scientific costing - letter from E. Miles Taylor. The Accountant, 60, 277.

The Accountant. (1919b). The Institute of Cost Accountants - letter from Thos. Haworth. The Accountant, 60, 416.

The Accountant. (1919c). Scientific costing - letter from Richard J.H. Ryall. The Accountant, 60, 483.

The Accountant. (1919d). Scientific costing - letter from R.J.H. Ryall. The Accountant, 61, 31.

The Cost Accountant. (1922a). Editorial: Manufacturers' amalgamation and the call for uniform costing methods. The Cost Accountant, 1, 155-156.

The Cost Accountant. (1922b). Notes and comments: Handling charges. The Cost Accountant, 1, 156.

The Cost Accountant. (1922c). Editorial: Standard costing. The Cost Accountant, 1, 175-176.

The Cost Accountant. (1922d). Notes and comments: Dunlop Rubber Co. Ltd. The Cost Accountant, 1, 176.

The Cost Accountant. (1922e). Discussion on 'The necessity for scientific costing' paper. The Cost Accountant, 1, 183-193.

The Cost Accountant. (1923a). Editorial: The accountant and auditor and costing. The Cost Accountant, 3, 181-182.

The Cost Accountant. (1923b). Notes and comments: Lectures on costing. The Cost Accountant, 3,182 .

The Cost Accountant. (1937). Costing terminology. The Cost Accountant, 16, 318-326.

The Cost Accountant. (1946-47). List of past presidents. The Cost Accountant, 25, inside of front cover.

The Cost Accountant. (1955). First award of the Institute gold medal. The Cost Accountant, 34, 62-63. 
The Economist Historical Archive 1843-2006. Retrieved May 25, 2010, from, http://www.tlemea.com/economist

The Incorporated Accountants' Journal. (1904). Cost accounts. The Incorporated Accountants' Journal, May, 175-176.

The Times Digital Archive 1785-1985. Retrieved June 4, 2010, from http://infotrac.galegroup.com

Tholfsen, T.R. (1967). Historical Thinking: An Introduction. New York: Harper \& Row.

Todman, J.C. (1922). The necessity for scientific costing. The Cost Accountant, 1, 179-183.

Tosh, J. and Lang, S. (2002). The Pursuit of History: Aims, Methods and New Directions in the Study of Modern History. Harlow: Pearson Education Ltd.

Urwick, L.F. (1929), The Meaning of Rationalisation, London: Nisbet \& Co.

Von Humboldt, W. (2008). On the historian's task. In A. Budd (Ed.), The Modern Historiography Reader (pp.167-171). London and New York: Routledge.

Warwick, T.H. (1888). Shipbuilders' accounts. The Accountant, 14, 663-665.

Whitehouse, G.E. (1922). The human element in cost accounting. The Cost Accountant, 1, 248249.

Whitston, K. (1996). Scientific management and production management practice in Britain between the wars. Historical Studies in Industrial Relations, 1(1), 47-75.

Wild, J.A. (1921). Fundamental principles of scientific costing. The Cost Accountant, 1, 35, 53, 73 and 94.

Willmott, H. (1986). Organising the profession: a theoretical and historical examination of the development of the major accountancy bodies in the UK. Accounting, Organizations and Society, 11(6), 555-580. 